\title{
抗ヒスタミン劑のエピレナミン作用 增强に關する研究
}

内田亭

（日本醫科大學藥理學教室〔樂秋要教授〕）

（昭和28年12月14日受付）

\begin{abstract}
I. 緒
言

周知の如くエピレナミン其他の交感神經効果樂はアレルギー性疾患の主な治潦樂を第するのであるが, Jen

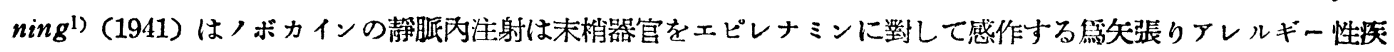
患に對して効果的であると云万事を報告した. Mancke とOrzechowski2) (1948) は教胝內に注射したノボカ1 ンが組織分子をエピレナミンに對して，感作寸るのは，ボカインがェピレナミンの分解酲素であるアミノォキ シダーゼに依るエピレナミンの破壞を抑制する篇であると云万事を發表した。他方コカイン及び，其の他の局所

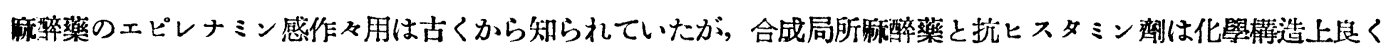

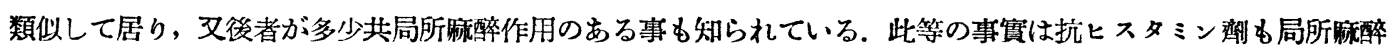
樂と同樣, エピレナミン感作々用があるのではないかと云5事を榎示するるのであり, 果して左羕な作用がある とすれば抗ヒスタミン劑のアレルギー性疾患に對する効果る勿論, その主なるるのは抗ヒスタミン作用に佐るる

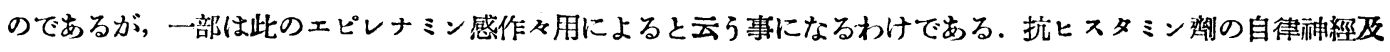
びェピレナミンとの關係に就ては未だ充分なる研究はなされていない樣であり, 從つて私は此等抗七スタミン判 のエピレナミン及び各種甈器の交感神經, 迷走神經に及ぽす影響, 並びにアミノオキシダーゼに對する作用に關 して矿究を行い, その結果を茹に一括して報告与る次第である.
\end{abstract}

\section{II. 农 驗 方 法}

惯檢動物としては蟇及び家鬼，靯，を使用しそわ等はすべて成熟したものを用い特に蓦は體重200g前後の冬 眠中のものを使用した.

赛驗に用いた抗ヒスタミン劑は，Dimethylaminoäthylbenzhydrylether hydrochlorid (Benadryl), N. dimethylaminoäthylphenothiazin hydrochlorid(Anergen), N,N-dimethyl-N'-phenyl:N'-(2-thienylmethyl)äthylendiamin monohydrochlorid (Diatrin) である. エピレナミンは監酸エピレナミン（三共裂）を用い此

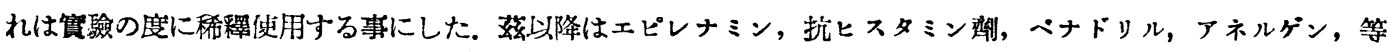

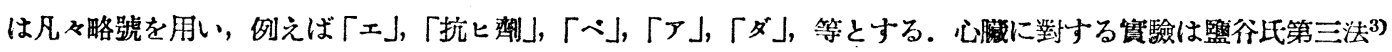

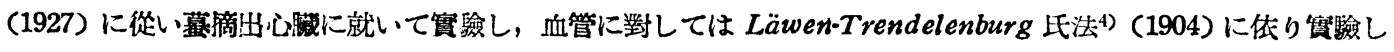

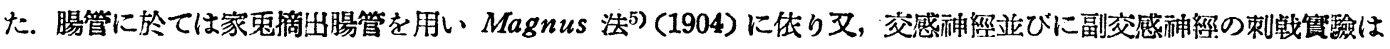

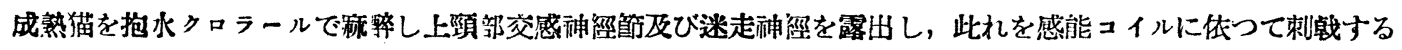
場合に於ける瞬膜の運動並びに血㗨の變化を煤㮒紙上に描記せしめた。

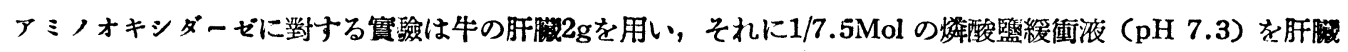

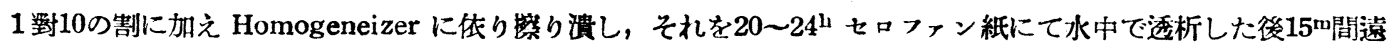

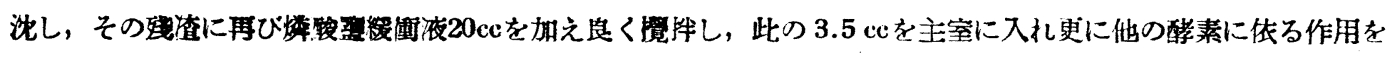


除外寸る笉に $\mathrm{NaCN} 1 \mathrm{mg}$ ，更に又 0.027 見定の $\mathrm{NaOH} 1 \mathrm{cc}$ に溶した「执七狱」を一諸にする。副空には 0.04

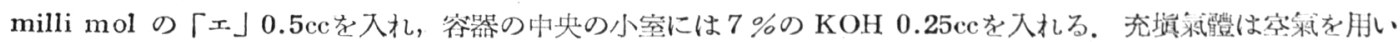

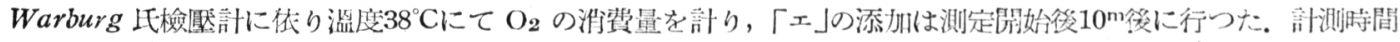

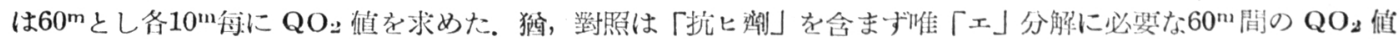
である。

\section{III. 實 驗 成 績}

\section{a) 抗ヒスタミン劑の作用}

\section{A 、慕摘出心臟に於ける賽驗}

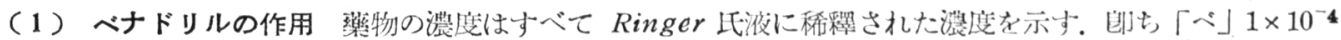

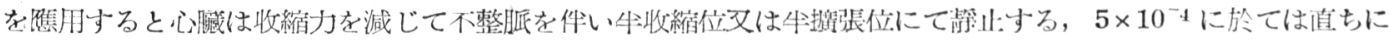

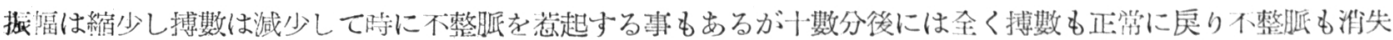

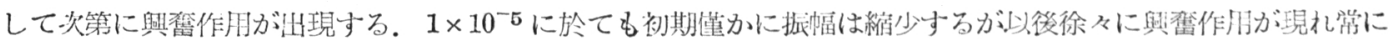

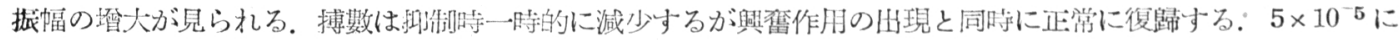

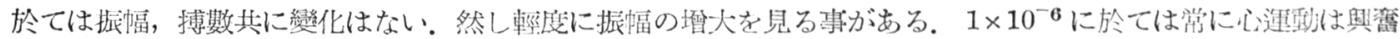

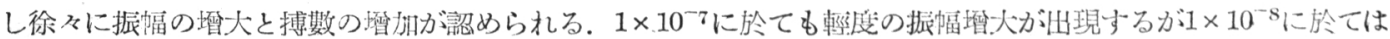
振愊，搏数共に變化なきか，或は僅かに振湢の㫮大が見られるの久である。

（2）アネルゲンの作用 $1 \times 10^{-4}$ に於ては「へ」同樣振揊は直ちに縮少し，不整脈老件い收皮力在減じて

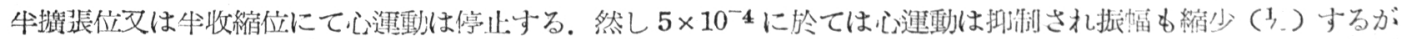

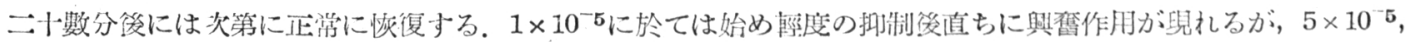

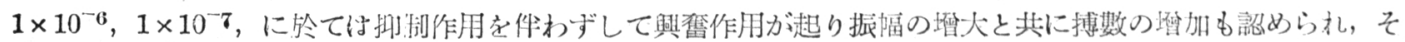

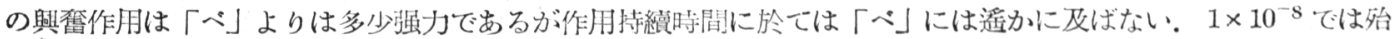
んど無作用か或は慬かに興奮作用の出現寸る埸合がある

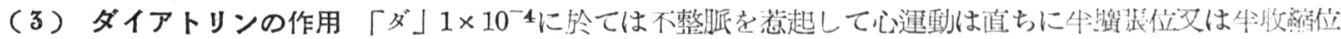

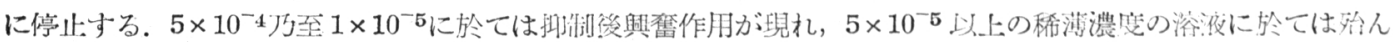
ど抑制作用を伴わずして「ア」同樣興樣作用を虽し， $1 \times 10^{-} 8$ に於ては殆んど哭作用である。

b) 抗ヒスタミン劑のエピレナミン作用に及ぼす影響

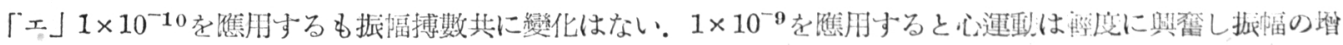

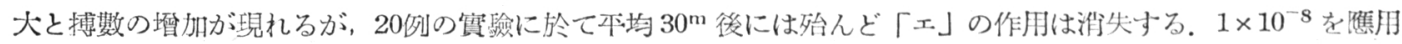

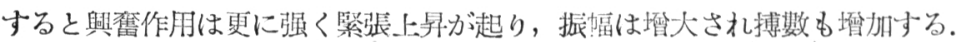

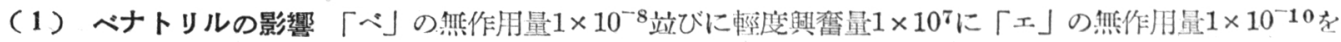

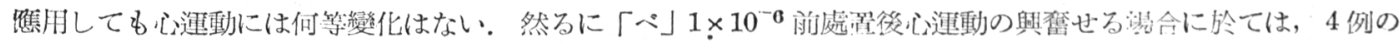
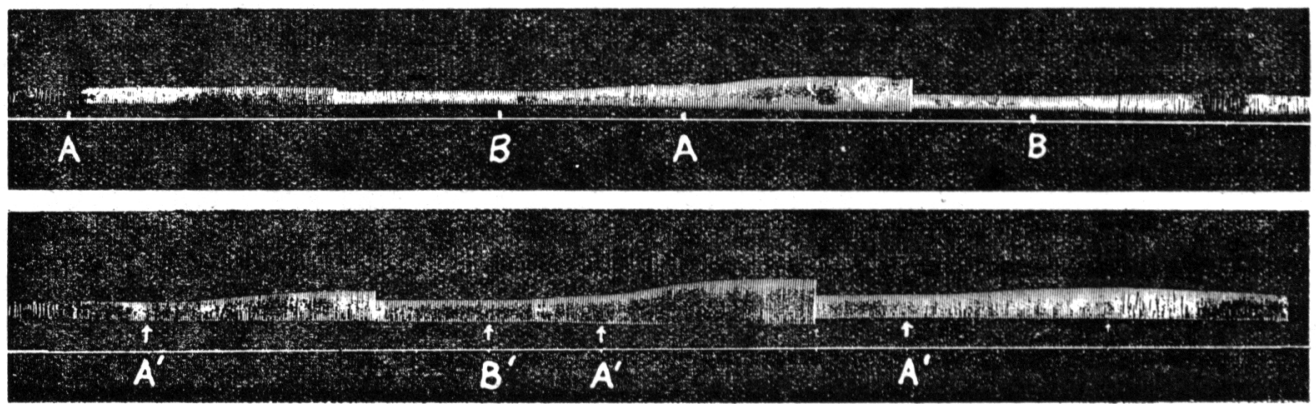

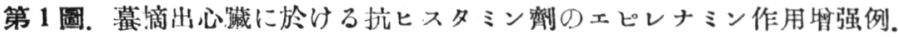

A. $1 \times 10^{-10}$ ×ピレナミン．B． $1 \times 10^{-6}$ ベナドリル．

$\mathrm{A}^{\prime}$. $1 \times 10^{-9}$ ×ピレナミン。 $\mathrm{B}^{\prime} .1 \times 10^{-8}$ アネルゲン, 時記間隔 $3^{5}$. 


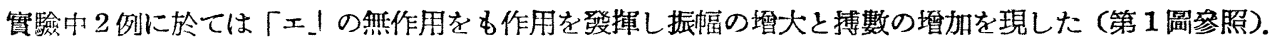

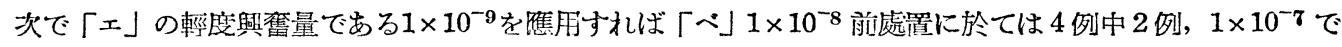
は 4 例中 3 例, $1 \times 10^{-8}$ に於ては 6 例中 5 例に於て「土」感作从用が發現し，特に「へう $1 \times 10^{-6}$ 隹用後に於ては 著时で「エ」作用の發現速度は對照の約 2 倍程速くなり, 振幅の增大は 1.7 倍, 作用持續時間:は 2 3 倍の延長が

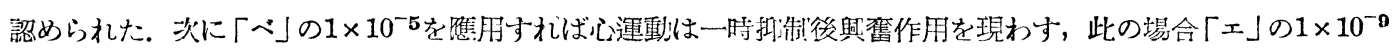

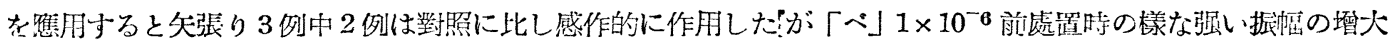

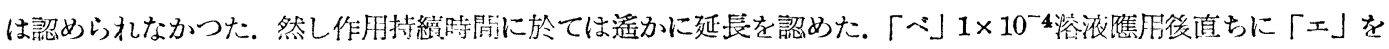

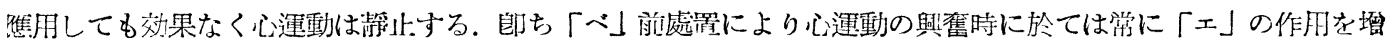

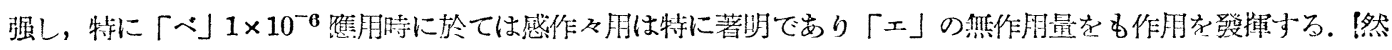

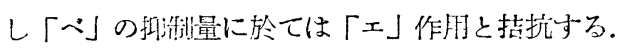

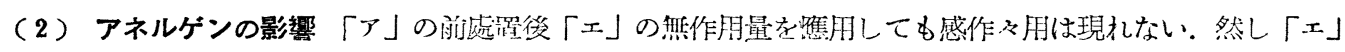

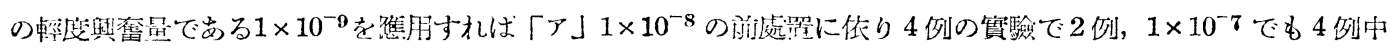

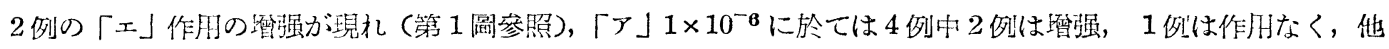

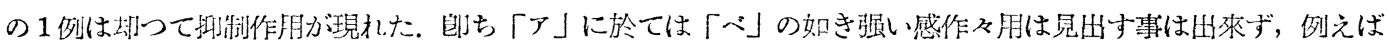

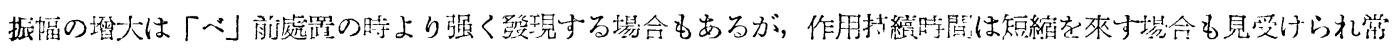

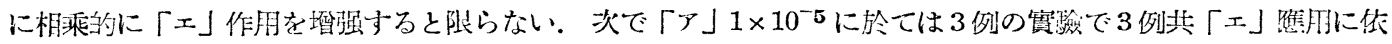

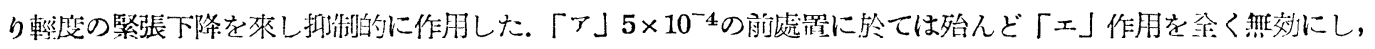

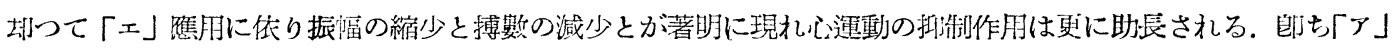

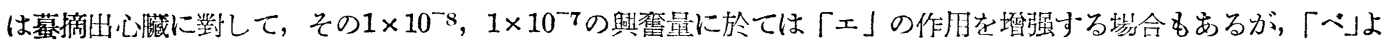
りは弱く殊にその抑制量に於ては「土」作用と拮抗し且つその拮抗作用は「べ」りは滛をに强力である.

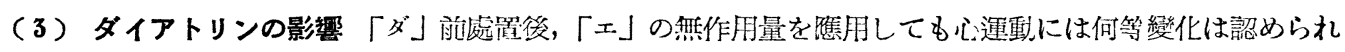

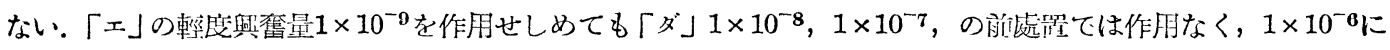
於て慬かに 4 例中 2 例に於て「エ」作胢の增强を見大が何れも「へ」よりは作朋弱く相和作用の如くであり，1×

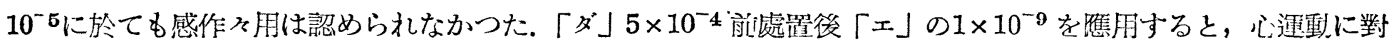

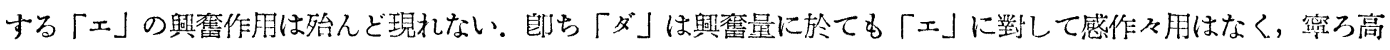
濃度 $\left(5 \times 10^{-4}\right)$ に於ては「エ」の作用と描扰する。

\section{B. 暮後肢血管に對する作用}

\section{（1） ベナドリルのエピレナミン作用に及ぼす影響}

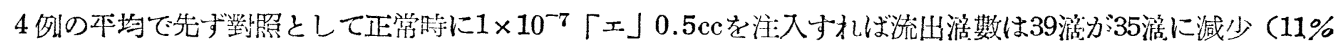

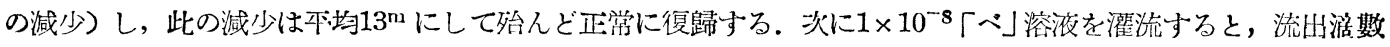

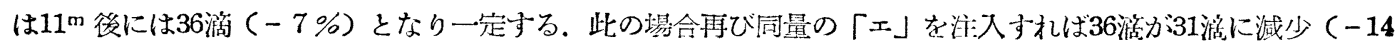
\%) し惔復に $14^{\mathrm{m}}$ を要した。

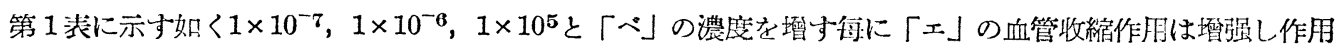

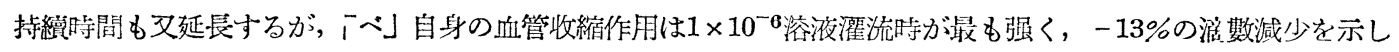
「エ」感作々用も著明である. 即ち「へ」は蟇血管に對して收縮的に作用し「「エ」の血管收縮作用を相乘的に增 强する.

\section{（2） アネルゲンのエピレナミン作用に及ぼす影響}

$\left\lceil ア 」 1 \times 10^{-8}\right.$ 溶液に於ては本均 $11 \%$ 流出涺數の減少を來すが，「エ」の血管收縮作用に對しては犬した作

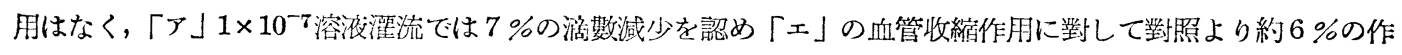
用增强を示し滴數洃復時間も䱿度の延長を認めた。然るに $1 \times 10^{-6}$ の「ア」溶液を潅流すると， 5 例の實驗に於

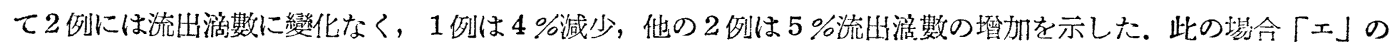
$1 \times 10^{-7}$ 溶液 $0.5 \mathrm{cc}$ を注入すると「ア」灌流に恢り流出涺數に變化なきか，或は減少を示した 3 例に於ては何れる

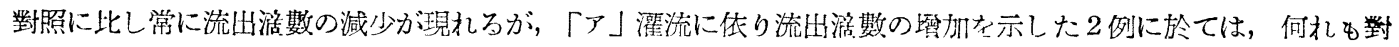

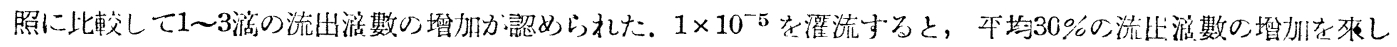




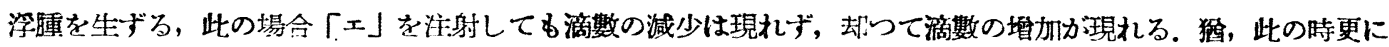

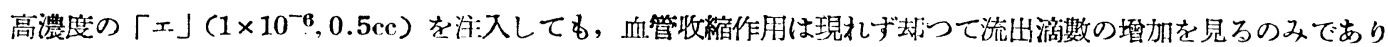

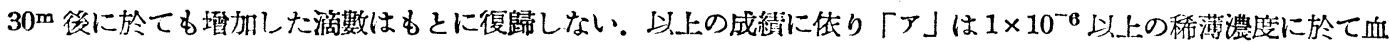

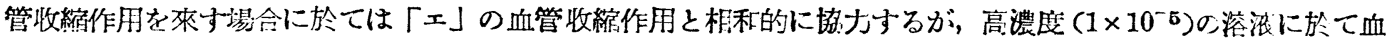

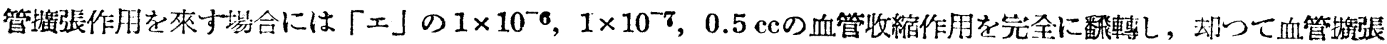
作用が現机る。

\section{（3）ダイアトリンのエピレナミン作用に及无す影䇺}

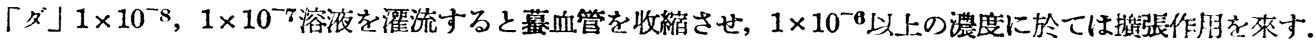

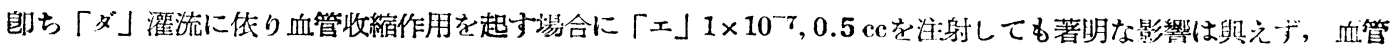
推張作用を呈する $1 \times 10^{-6}$ 以上の高濃度に於ては，「エ」の血管收縮作用を「ア」同樣完全に翻轉させ湔に血管》 啮張作用を招來与る。

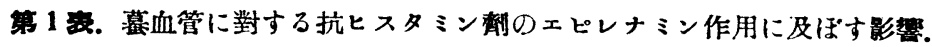

\begin{tabular}{|c|c|c|c|c|c|c|c|c|c|c|}
\hline \multirow{3}{*}{ 「抗ヒ敖」 } & \multirow{3}{*}{ 孉流濃度 } & \multirow{3}{*}{ 䮋 數 } & \multirow{2}{*}{\multicolumn{3}{|c|}{ リンダル 液 }} & $\frac{\text { 灌 流 }}{\text { 作用持續 }}$ & \multicolumn{4}{|c|}{ 抗七スタ 、 $ン$ 溶液灌流 } \\
\hline & & & & & & \multirow{2}{*}{$\begin{array}{l}\text { 作用持續 } \\
\text { 時間(分) }\end{array}$} & \multicolumn{3}{|c|}{ ×ピレナミン 洼 射 } & \multirow{2}{*}{$\begin{array}{l}\text { 作用持續 } \\
\text { 時間(分) }\end{array}$} \\
\hline & & & 前(滴數) & & 後 & & & 前 & 後 & \\
\hline \multirow{4}{*}{$\begin{array}{l}\text { ஓ゙ } \\
\text { ナ } \\
\text { ド } \\
\text { リ } \\
\text { ル }\end{array}$} & $10^{-8}$ & 4 & 39 & 35 & $(-11 \%)$ & $13^{m}$ & 36 & $(-7 \%)$ & $31(-14 \%)$ & $14^{\mathrm{m}}$ \\
\hline & $10^{-7}$ & 5 & 43 & 38 & $(-12 \%)$ & 14 & 40 & $(-9 \%)$ & $33(-18 \%)$ & 19 \\
\hline & $10^{-6}$ & 3 & 41 & 37 & $(-9 \%)$ & 11 & 36 & $(-13 \%)$ & $27(-25 \%)$ & 28 \\
\hline & $10^{-5}$ & 3 & 43 & 39 & $(-9 \%)$ & 12 & 40 & $(-6 \%)$ & $29(-28 \%)$ & $30 \mathrm{~m}$ 以上 \\
\hline \multirow{5}{*}{$\begin{array}{l}ア \\
⿱ 亠 \\
ル \\
\qquad \\
ン\end{array}$} & $10^{-8}$ & 4 & 42 & 37 & $(-12 \%)$ & 13 & 38 & $(-11 \%)$ & $33(-13 \%)$ & 12 \\
\hline & $10^{-7}$ & 4 & 42 & 37 & $(-12 \%)$ & 12 & 39 & $(-7 \%)$ & $32(-18 \%)$ & 15 \\
\hline & $10^{-6}$ & 5 & 41 & 37 & $(-9 \%)$ & 9 & 41 & $\left(\begin{array}{ll}0\end{array}\right)$ & $34(-16 \%)$ & 15 \\
\hline & $10^{-5}$ & 4 & 42 & & $(-12 \%)$ & 12 & 54 & $(+30 \%)$ & $57(+6 \%)$ & $30^{\mathrm{m}}$ 以上 \\
\hline & $* 10^{-5}$ & 3 & 44 & & $(-40 \%)$ & 19 & 53 & $(+22 \%)$ & $59(+12 \%)$ & " \\
\hline \multirow{4}{*}{$\begin{array}{l}\text { ダ } \\
1 \\
> \\
\vdash \\
y \\
y\end{array}$} & $10^{-8}$ & 3 & 36 & 32 & $(-12 \%)$ & 13 & 33 & $(-9 \%)$ & $28(-15 \%)$ & 12 \\
\hline & $10^{-7}$ & 3 & 39 & 35 & $(-10 \%)$ & 11 & 36 & $(-7 \%)$ & $32(-11 \%)$ & 12 \\
\hline & $10^{-6}$ & 5 & 44 & 40 & $(-9 \%)$ & 10 & 42 & $(-3 \%)$ & $39(-7 \%)$ & 10 \\
\hline & ${ }^{*} 10^{-5}$ & 3 & 37 & 23 & $(-38 \%)$ & 15 & 43 & $(+15 \%)$ & $49(+14 \%)$ & $30^{\mathrm{m}}$ 以上 \\
\hline
\end{tabular}

註. *の場合に於てのみ $1 \times 10^{-6}, 0.5 \mathrm{cc} の \Gamma ェ 」$ を注射した。

\section{C. 家鬼摘出腸管に對する作用}

\section{a) 抗ヒスタミン奋の作用}

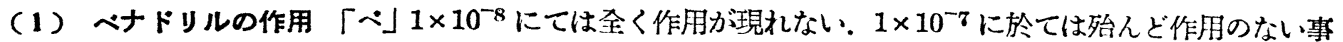
もあるが輕度の振幅縮少を起し，次で䇣張下降が現れるも振幅は徐々に恢復し時には却つて暂大寸る事もあるが

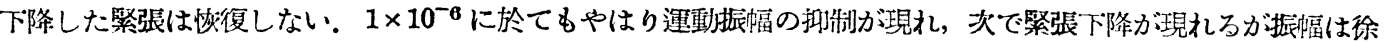

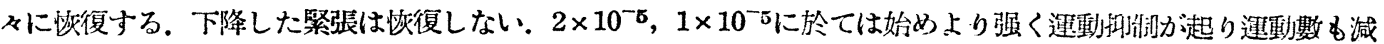

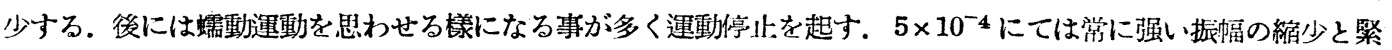
張下降を起し腸管は值ちに弛綏位に静止する。

（2）アネルゲンの作用「ア」す「べと同樣 $1 \times 10^{-8}$ では全く作用なく $1 \times 10^{-}$てに於ても無作用か，或は 輕度に振幅の縮少を來す事があるが，1×10-6では振幅の縮少と緊張下降が現れ下降した緊張は恢復しない，1×

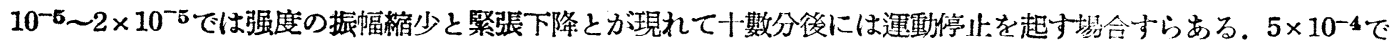
は勿論㨁ちに運動は弛緩位に停止する.

（3）ダイアトリンの作用「ダ」1×10-8 では作用はない.1×10-7では振幅には大した變化はないが僅か 


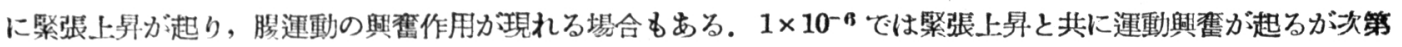
に振幅は縮少し, 時及螨動運動を思わせる樣になり運動數も減少する. 然し十數分後には振幅も稌及に恢復し祭 張上昇子又もとに戻る. $1 \times 10^{-5}, 2 \times 10^{-5}$ では始めより牛收縮位にて振幅の縮少と, 運動數の減少々が現れるが, 次第に緊張下降と蠕動運動が起り二十數分後には運動停止を見る事がある。 $5 \times 10^{-4}$ では强度の振幅縮少と共に 㝳收縮位に運動の静止を來し, 緊張下降が現れて逐には弛緩位となる。

\section{b）抗ヒスタミン劑のエピレナミン作用に及ぼす影響}

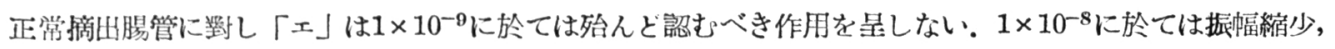
緊張下降を來し運動数は時に減少与る。 $1 \times 10^{-7}$ に於ては作用は更に强く，運㡖は一時停止し䜿張は著明に低下 ナるも腸管は間もなく運動を始め, 振幅も增大し漸次恢復に向う。

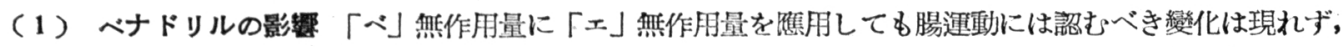
又「エ」の $1 \times 10^{-7}$ を加えても「エ」作用の貲强は認められなかつた。

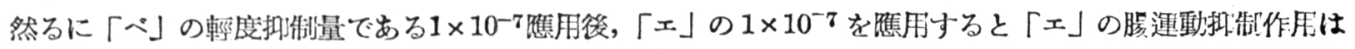
更に增强し緊張下降, 振幅縮少を招來して作用持續時間も文延長する (第 2 訚參照)。「へ」の $1 \times 10^{-0}$ の前處罚 では「エ」の感作及用は更に增强される。

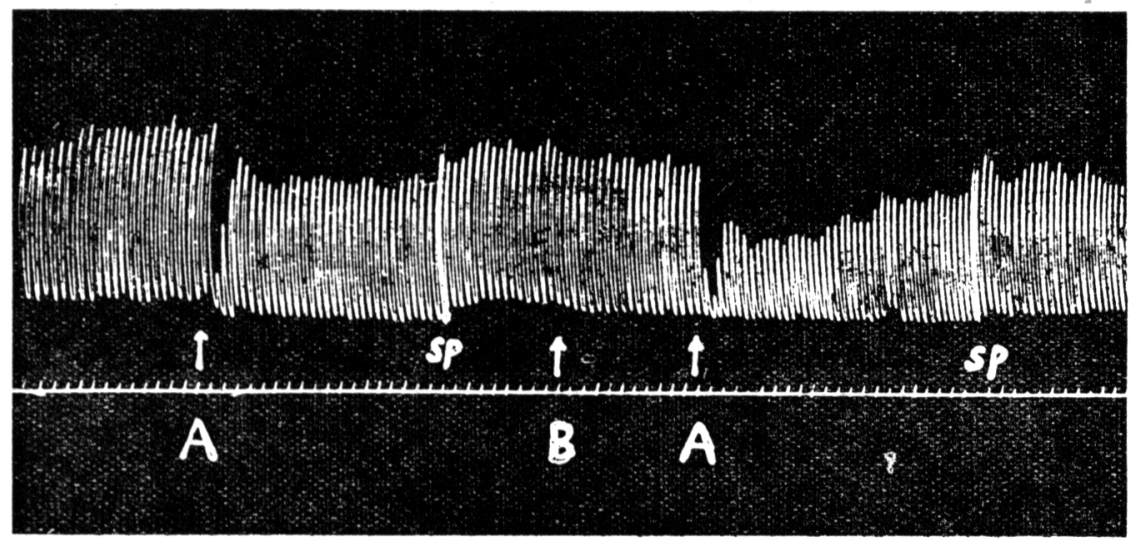

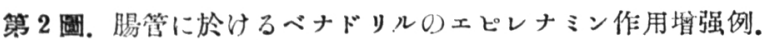

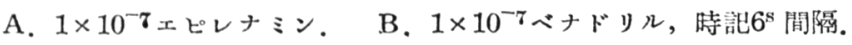

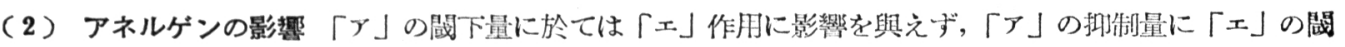

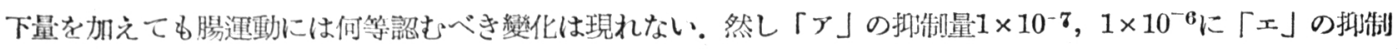

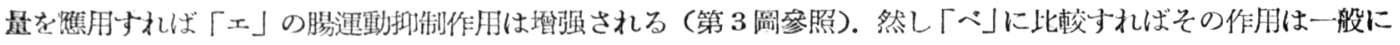

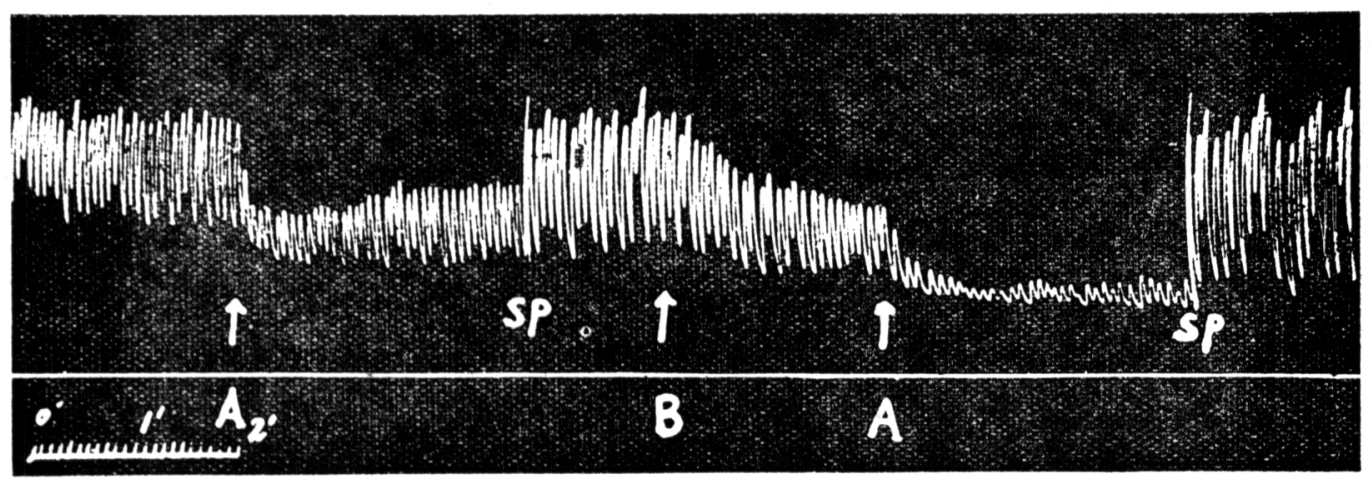

第 3 鱼。腸管に於けるアネルゲンのエピレナミン作用堆强例.
A. $1 \times 10^{-7}$ ×ピレナミン.
B. $1 \times 10^{-6}$ アネルゲン. 
弱い。

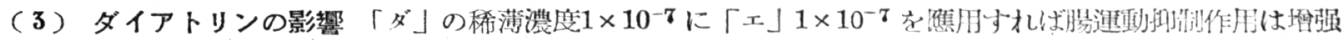

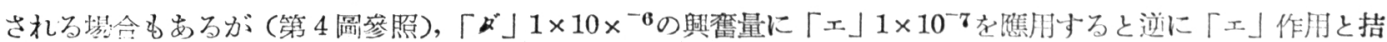

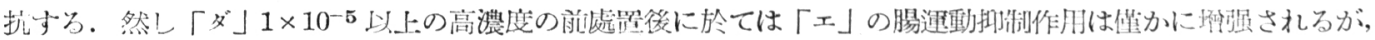

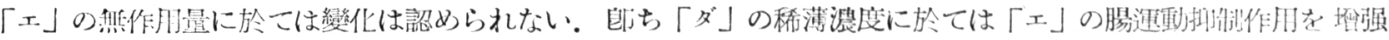

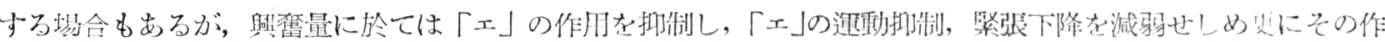
用持縞時間をも短縮せししめる。

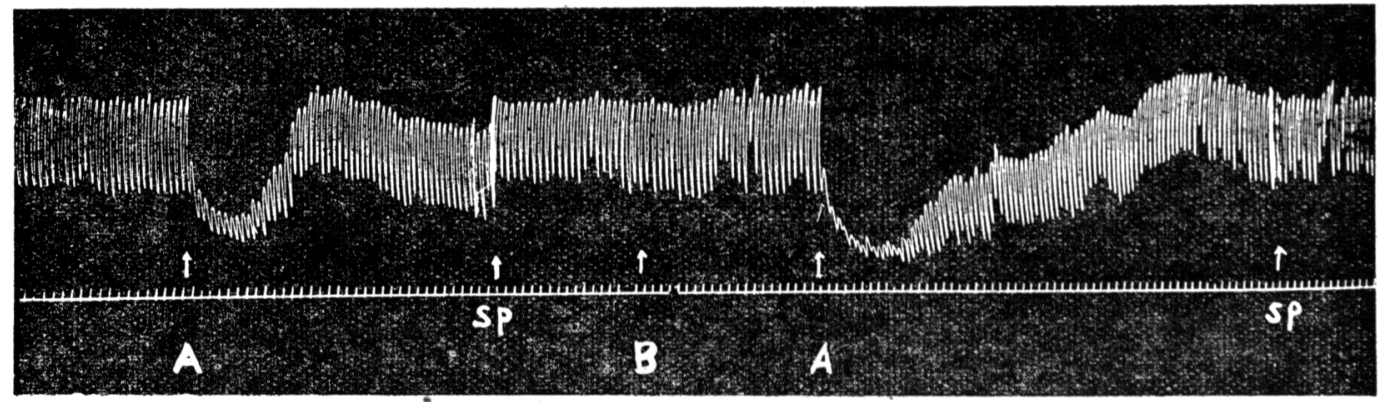

第 4 龽。腸管に於けるダイアトリンのエピレナミン作用の埔强例、

A. $1 \times 10^{-7}$ ×ピレナミン. B. $1 \times 10^{-7}$ ダイアトリン, 時能6 间路。

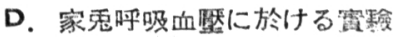

\section{a) 抗ヒスタミン唯の作用}

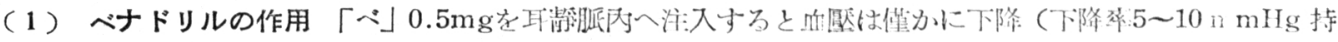

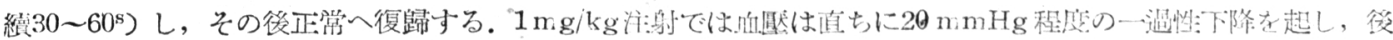

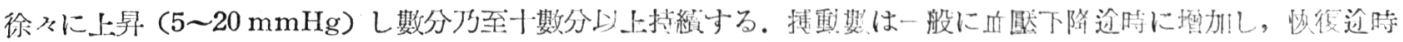

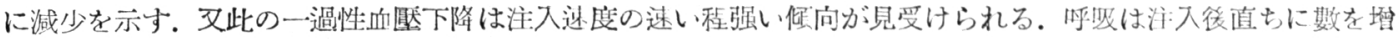

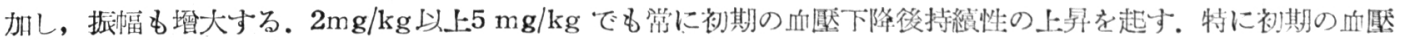

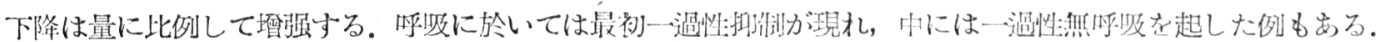

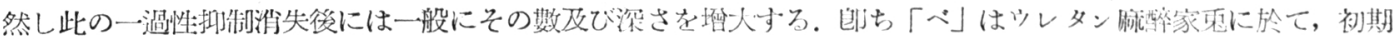

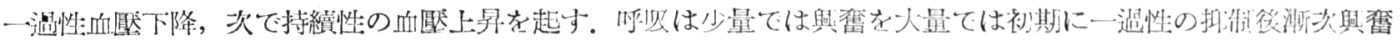
作用在起与.

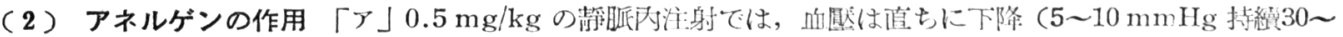

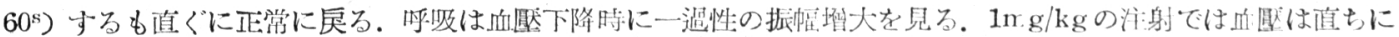
$20 \mathrm{mmHg}$ 程度の一過性下降を起寸が，「心」の如く下降後の持續性血具上昇は起らない. 㕛搏動数も「ぺ」とは

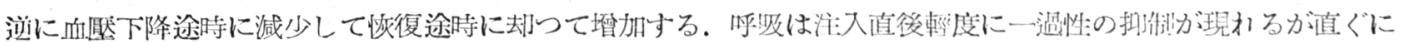

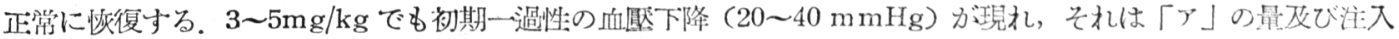

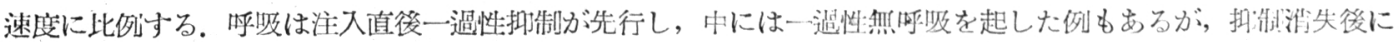

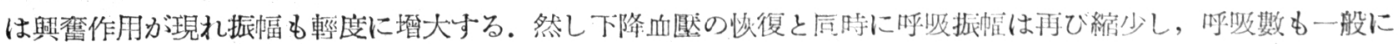

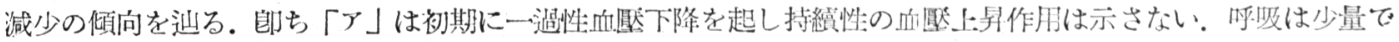

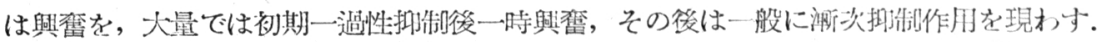

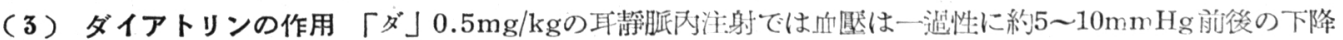

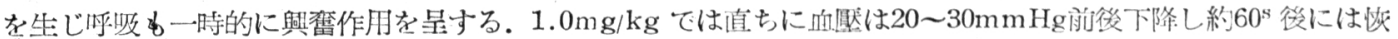

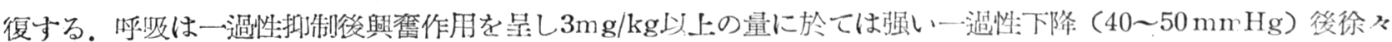

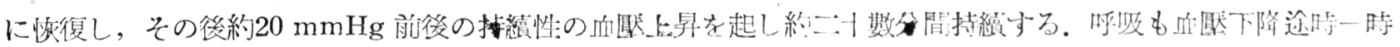

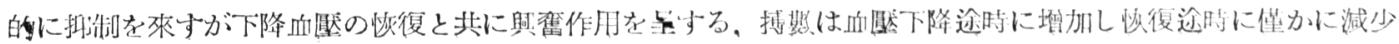




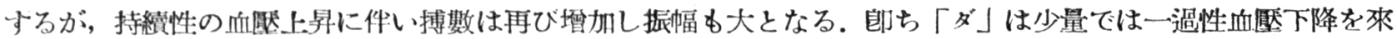

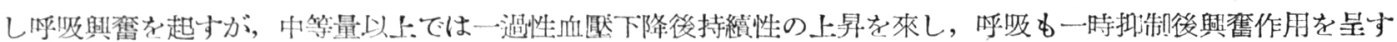
る.

\section{b）抗ヒスタミン製のエピレナミン作用に及ぼす影響}

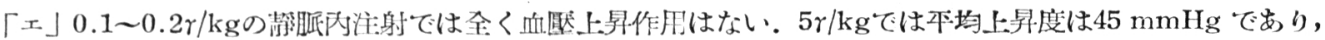
$10 \mathrm{r} / \mathrm{kg}$ では最低 $46 \mathrm{mmHg}$, 最高76 mmHgの上昇老來し10例の本均上昇度は60 $\mathrm{mmHg}$ で上昇卒は70\%である。

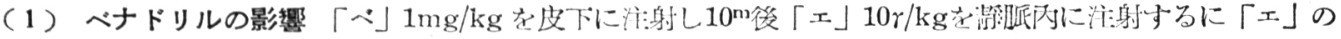

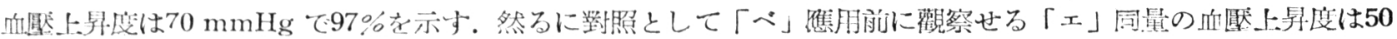

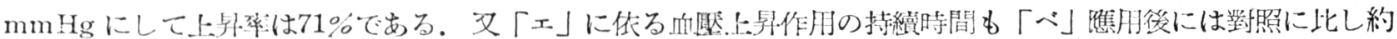

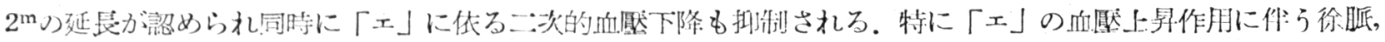

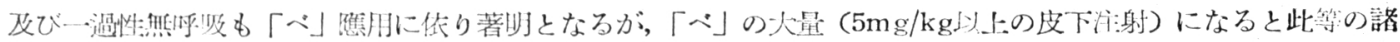

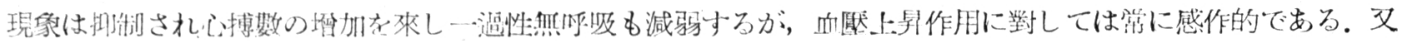

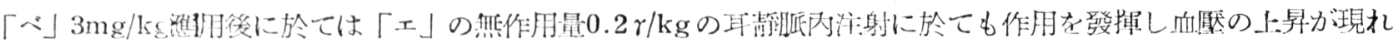
3.

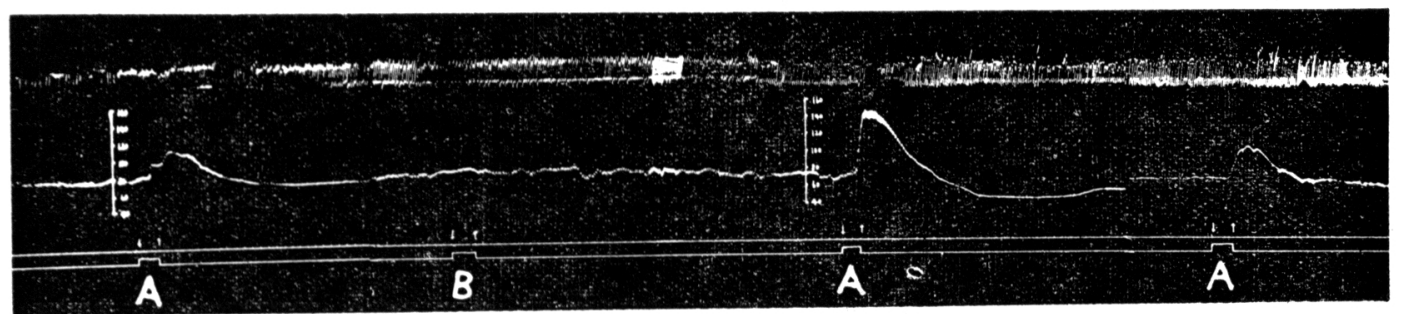

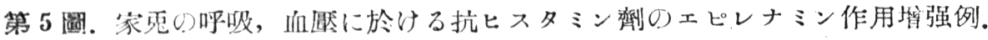

A. $5 r / \mathrm{kg}$ エピレナミン静服内注射。B. $3.0 \mathrm{mg} / \mathrm{kg}$ ベドリル皮下注射.

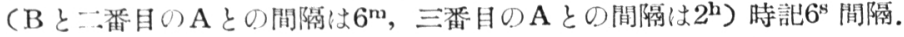

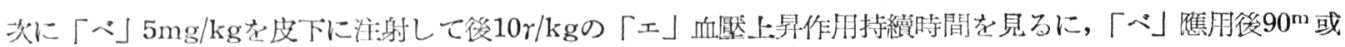
は更に長く $120^{\mathrm{m}}$ 後にも份作用が續いている. $1 \mathrm{mg} / \mathrm{kg}$ では短縮して30〜60 $0^{\mathrm{m}}, 0.5 \mathrm{mg} / \mathrm{kg}$ では20〜30

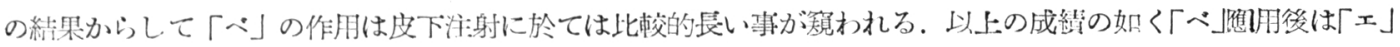

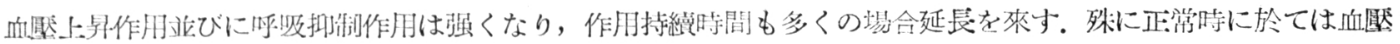

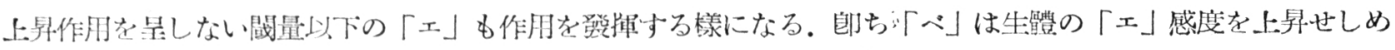
๖.

第 2 表. ベナドリルに依るエピレナミン血款作用の秒化.

\begin{tabular}{|c|c|c|c|c|c|c|c|c|}
\hline \multirow{2}{*}{ 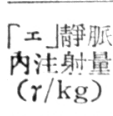 } & \multirow[b]{2}{*}{ 例 數 } & \multicolumn{2}{|c|}{ 「べ沫 射 前 } & \multirow{2}{*}{$\begin{array}{l}\text { 「゙披下 } \\
\text { 注 射量 } \\
(\mathrm{mg} / \mathrm{kg})\end{array}$} & \multirow[b]{2}{*}{ 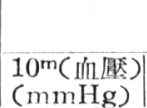 } & 「べ」 & 琈 & \\
\hline & & $\begin{array}{l}\text { 正常血焣 } \\
(\mathrm{mmHg})\end{array}$ & 「土」に依る & & & 「ェ」に依る & $\begin{array}{l}30^{\mathrm{m}}(\text { 血厭 }) \\
(\mathrm{mmHg})\end{array}$ & 「土」に依る \\
\hline 10 & 1 & 76 & $\begin{array}{l}(\mathrm{mmHg}) \\
(+) 42(55 \%)\end{array}$ & 0.5 & 76 & $\begin{array}{l}(\mathrm{mmHg}) \\
(+) 44(58 \%)\end{array}$ & 77 & $\begin{array}{l}(\mathrm{mmHg}) \\
(+) 41(53 \%)\end{array}$ \\
\hline 11 & 2 & 70 & $(+) 50(71 \%)$ & 1.0 & 72 & $(+) 70(97 \%)$ & 71 & $(+) 58(82 \%)$ \\
\hline "1 & 3 & 79 & $(+) 46(58 \%)$ & 3.0 & 70 & $(+) 54(77 \%)$ & 70 & $(+) 60(84 \%)$ \\
\hline 11 & 4 & 73 & $(+) 60(82 \%)$ & 5.0 & 73 & $(+) 72(98 \%)$ & 71 & $(+) 74(103 \%)$ \\
\hline 0.2 & 5 & 80 & $(+) 2(2 \%)$ & 3.0 & 76 & $(+) \quad 3 \quad(4 \%)$ & 70 & $(+) 7 \quad(9 \%)$ \\
\hline
\end{tabular}

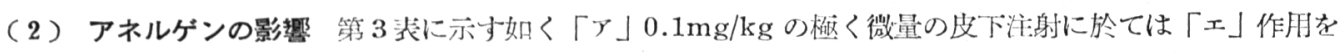

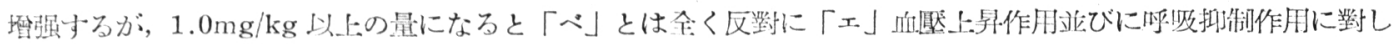

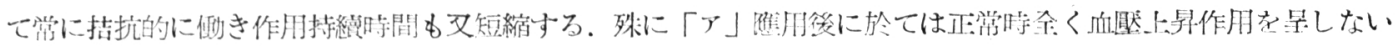

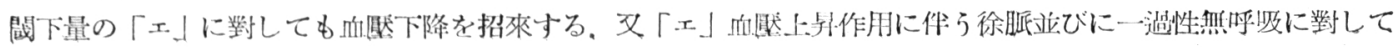




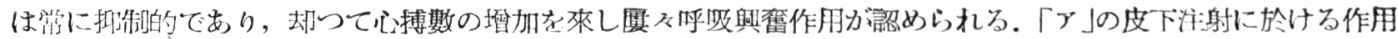

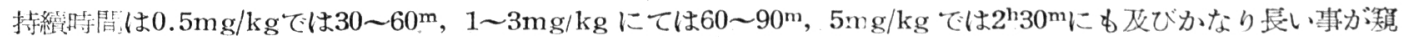

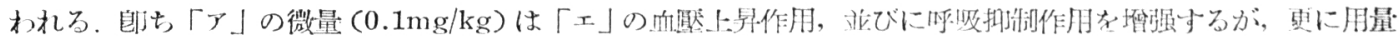
を塯すと反對に「土」作月老抑揦与る。

第3患.アネルゲンに依るエピレナミン血屒作用の整化。

\begin{tabular}{|c|c|c|c|c|c|c|c|c|}
\hline \multirow{2}{*}{$\begin{array}{c}\Gamma x \text { 静脈 } \\
\text { 内注射量 } \\
(\gamma / \mathrm{kg})\end{array}$} & \multirow{2}{*}{ 例 數 } & \multicolumn{2}{|c|}{ 「ア」泩 射 前 } & \multirow{2}{*}{$\begin{array}{l}\text { 「披下 } \\
\text { 沌 射量 } \\
(\mathrm{mg} / \mathrm{kg})\end{array}$} & \multicolumn{4}{|c|}{$\lceil ア 」$} \\
\hline & & $\begin{array}{l}\text { 正常血㗨 } \\
(\mathrm{mmHg})\end{array}$ & 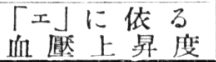 & & $\begin{array}{l}10^{\mathrm{m}}(\text { 血卙) } \\
(\mathrm{mmHg})\end{array}$ & 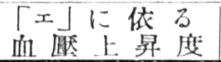 & $\begin{array}{l}30^{\mathrm{m}}(\text { 血国 }) \\
(\mathrm{mmHg})\end{array}$ & 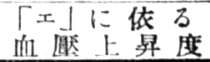 \\
\hline 5 & 1 & 83 & $\begin{array}{l}(\mathrm{mmHg}) \\
(+) 32(39 \%)\end{array}$ & 0.1 & 70 & $\begin{array}{l}(\mathrm{mmHg}) \\
(+) 34(48 \%)\end{array}$ & 70 & $\begin{array}{l}(\mathrm{mmHg}) \\
(+) 35(50 \%)\end{array}$ \\
\hline$" 1$ & 2 & 80 & $(+) 30(37 \%)$ & "1 & 74 & $(+) 42(57 \%)$ & 72 & $(+) 30(42 \%)$ \\
\hline "1 & 3 & 75 & $(+) 34(45 \%)$ & 0.5 & 68 & $(+) 32(45 \%)$ & 69 & $(+) 28(40 \%)$ \\
\hline 11 & 4 & 84 & $(+) 45(53 \%)$ & "1 & 86 & $(+) 44(51 \%)$ & 95 & $(+) 38(40 \%)$ \\
\hline 10 & 5 & 80 & $(+) 45(56 \%)$ & 1.0 & 67 & $(+) 35(52 \%)$ & 70 & $(+) 24(34 \%)$ \\
\hline "1 & 6 & 73 & $(+) 56(76 \%)$ & 5.0 & 73 & $(+) 30(41 \%)$ & 72 & $(+) 26(36 \%)$ \\
\hline 0.2 & 7 & 83 & $(+) 5(6 \%)$ & 3.0 & 75 & $(-) 9(-12 \%)$ & 70 & $(-) 9(-12 \%)$ \\
\hline
\end{tabular}

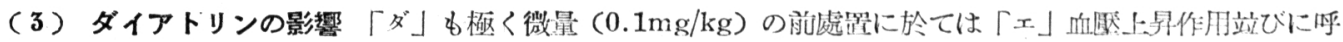

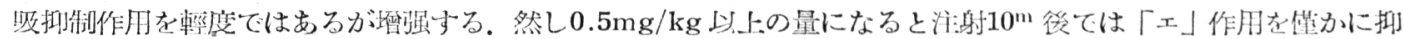

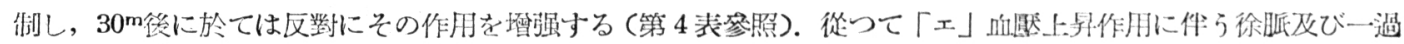

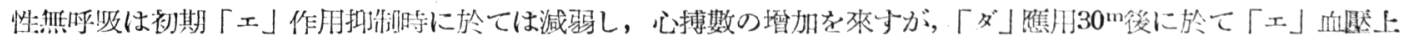

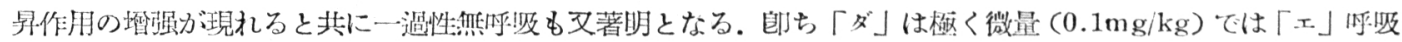

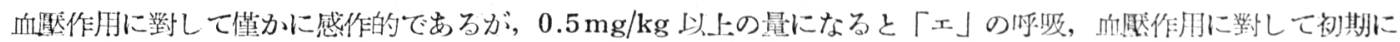

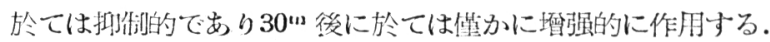

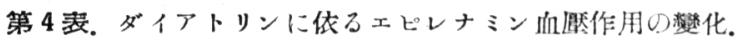

\begin{tabular}{|c|c|c|c|c|c|c|c|c|}
\hline \multirow{2}{*}{$\begin{array}{l}\text { } x \sqrt{\text { 静脈 }} \\
\text { 队注射量 } \\
(r / \mathrm{kg})\end{array}$} & \multirow[b]{2}{*}{ 例 數 } & \multicolumn{2}{|c|}{ 「ダ」汁，射 的 } & \multirow{2}{*}{$\begin{array}{l}\text { 「名披下 } \\
\text { 洼射量 } \\
(\mathrm{mg} / \mathrm{kg})\end{array}$} & \multicolumn{4}{|c|}{$\lceil\not ゙ 」$} \\
\hline & & 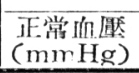 & 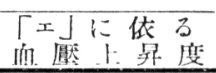 & & $\begin{array}{l}10^{\mathrm{m}}(\text { 血厚 }) \\
(\mathrm{mmHg})\end{array}$ & 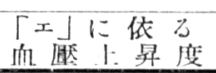 & 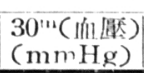 & 「土」に依る \\
\hline 5 & 1 & 82 & $\begin{array}{l}(\mathrm{mmHg}) \\
(+) 35(42 \%)\end{array}$ & 0.1 & 85 & $\begin{array}{l}(\mathrm{mmHg}) \\
(+) 41(48 \%)\end{array}$ & 80 & $\begin{array}{l}(\mathrm{mmHg}) \\
(+) 37(46 \%)\end{array}$ \\
\hline 10 & 2 & 80 & $(+) 48(60 \%)$ & 0.5 & 84 & $(+) 45(53 \%)$ & 78 & $(+) 50(64 \%)$ \\
\hline "1 & 3 & 78 & $(+) 55(70 \%)$ & 1.0 & 80 & $(+) 50(62 \%)$ & 73 & $(+) 60(82 \%)$ \\
\hline 11 & 4 & 72 & $(+) 41(57 \%)$ & 5.0 & 71 & $(+) 40(56 \%)$ & 71 & $(t) 53(74 \%)$ \\
\hline 0.2 & 5 & 80 & $( \pm) \quad 0$ & 3.0 & 78 & $( \pm) \quad 0$ & 76 & $(t) 2(3 \%)$ \\
\hline
\end{tabular}

\section{E．抗ヒスタミン製の自律神經刺戟効果に及ぼす影警}

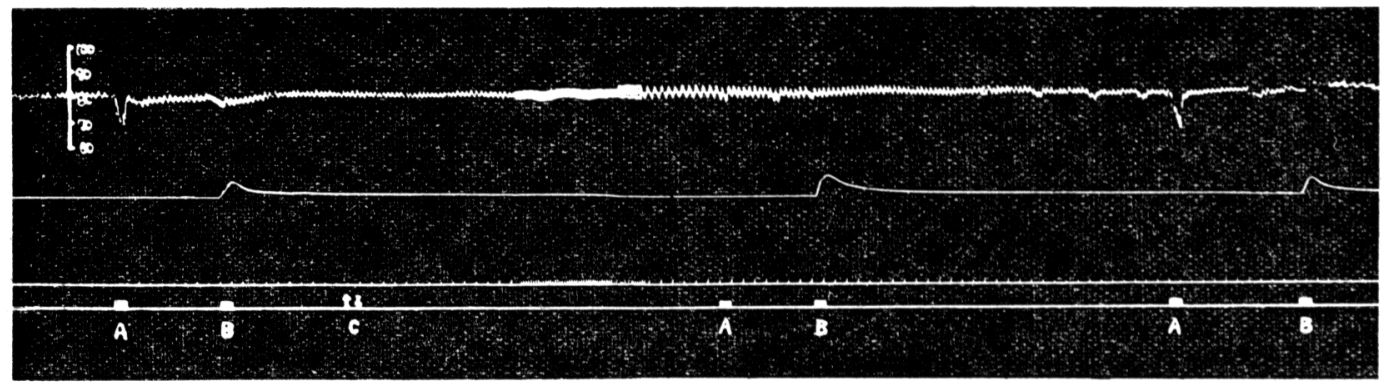

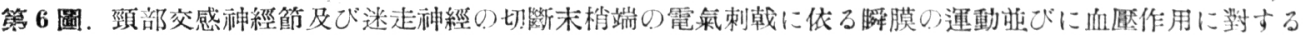
ベナドリルの感作例.

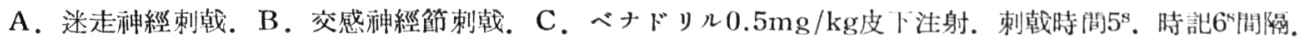


第 5 表。ベナドリルの自律神經刺戟効果に及ぼす影響。

\begin{tabular}{|c|c|c|c|c|c|c|c|}
\hline \multirow{2}{*}{ 例 數 } & \multirow{2}{*}{$\begin{array}{l}\text { 「披下 } \\
\text { 汒 射量 } \\
(\mathrm{mg} / \mathrm{kg})\end{array}$} & 交 & 感 & 經 & 副 & 交 感 神 & 經 \\
\hline & & $\begin{array}{l}\text { 注 射 前 } \\
(\mathrm{cm})\end{array}$ & $\begin{array}{c}\text { 注射10 }{ }^{m} \text { 後 } \\
(\mathrm{cm})\end{array}$ & $\begin{array}{l}30^{\mathrm{n}} \text { 後 } \\
(\mathrm{cm})\end{array}$ & $\begin{array}{c}\text { 注 射 前 } \\
(\mathrm{cm})\end{array}$ & $\begin{array}{c}\text { 注射 } 10^{\mathrm{m}} \text { 後 } \\
(\mathrm{cm})\end{array}$ & $\begin{array}{l}30^{\mathrm{m}} \text { 後 } \\
(\mathrm{cm})\end{array}$ \\
\hline 1 & 0.1 & 16.0 & $(+) 0.3$ & $( \pm) 0$ & 16.0 & $( \pm) 0$ & (土) 0 \\
\hline 2 & 0.1 & 19.0 & $(+) 0.5$ & $( \pm) 0$ & 18.0 & $( \pm) 0$ & (土) 0 \\
\hline 3 & 0.5 & 20.0 & $(+) 1.0$ & $(+) 0.7$ & 18.0 & $(-) 0.5$ & $(-) 0.2$ \\
\hline 4 & 0.5 & 21.0 & $(+) 1.0$ & $(+) 0.8$ & 18.5 & $(-) 0.5$ & $(-) 0.3$ \\
\hline 5 & 1.0 & 18.0 & $(+) 2.0$ & $(+) 2.0$ & 18.0 & $(-) 1.0$ & $(-) 1.5$ \\
\hline 6 & 1.0 & 19.0 & $(+) 1.5$ & $(+) 2.0$ & 17.0 & $(-) 0.5$ & $(-) 1.5$ \\
\hline 7 & 5.0 & 20.0 & $(+) 0 . \dot{5}$ & $(+) 0.5$ & 19.0 & $(-) 0.5$ & $(-) 2.5$ \\
\hline 8 & 5.0 & 19.0 & $(+) 0.5$ & $(+) 0.5$ & 18.0 & $(-) 1.5$ & $(-) 2.0$ \\
\hline
\end{tabular}

第 $5 \sim 7$ 表中, $\mathrm{cm}$ 單位の數字はコイル間の距離老示めす.

註. (十)はコイル間距攡の延長を示し，(一) は短縮を表す.

（1）べナドリルの作用「ヘ」の交感种經立立びに迷走秗經の刺㦸効果に及ぼす作用は，第 5 表に示す如く

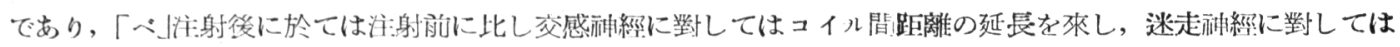

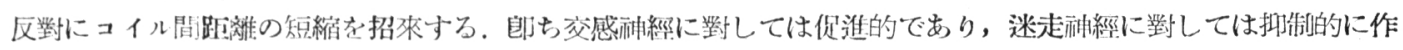
用与る。

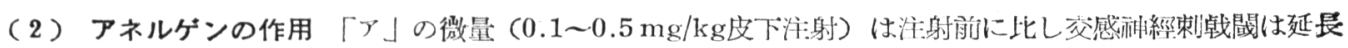

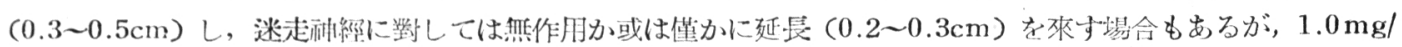
$\mathrm{kg}$ 以上の量に於ては交感, 迷走兩种繂に對して䳸斷的でもる(第6 表參照).

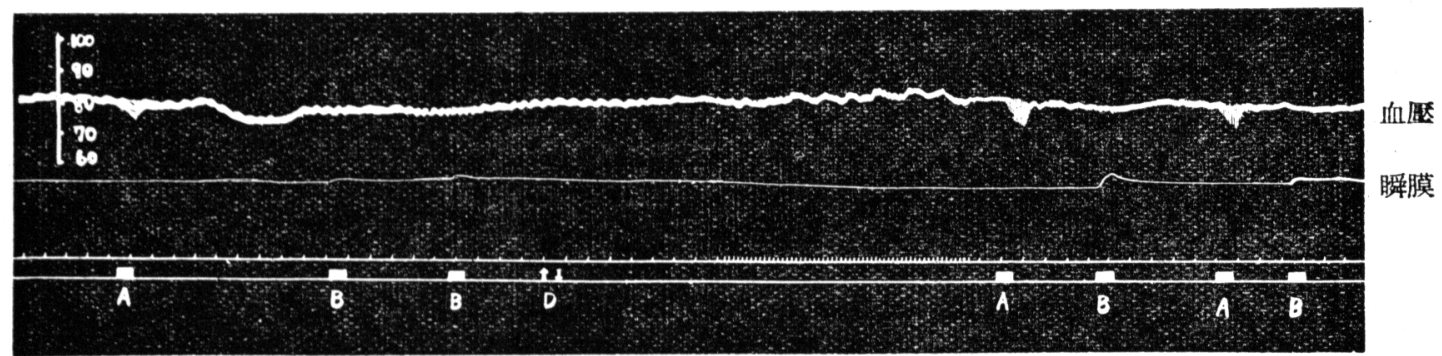

第7 圖. 到部交感神經節及び迷走神經の切院末梢端の)電氣刺戟に依る瞬膜の運動 前びに血摒作用に對するアネルゲンの感作例.

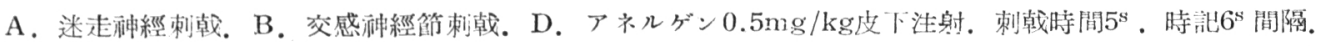

第 6 表.アネルゲンし)自律种經刺戟効果に及洔す影響.

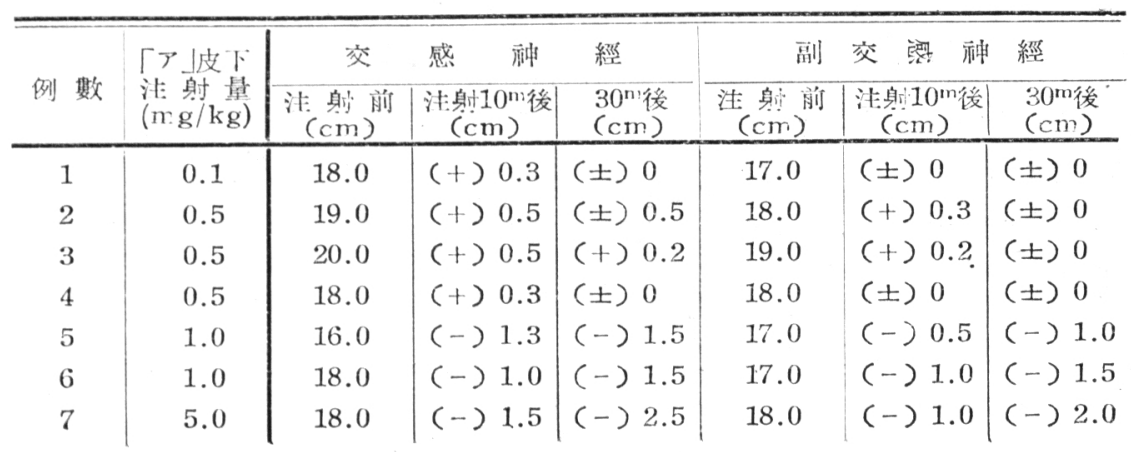




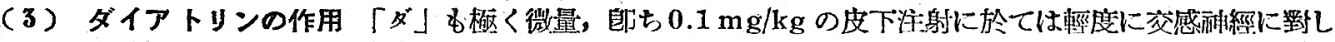

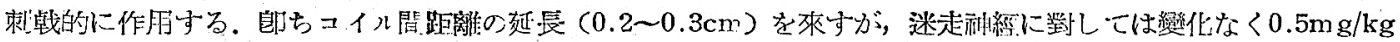

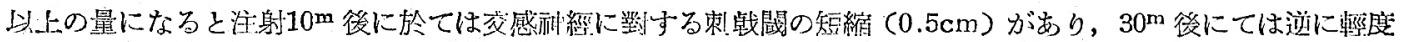

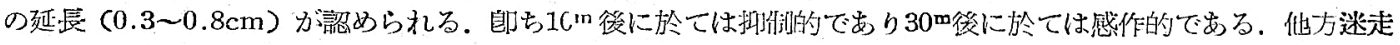

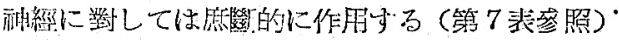
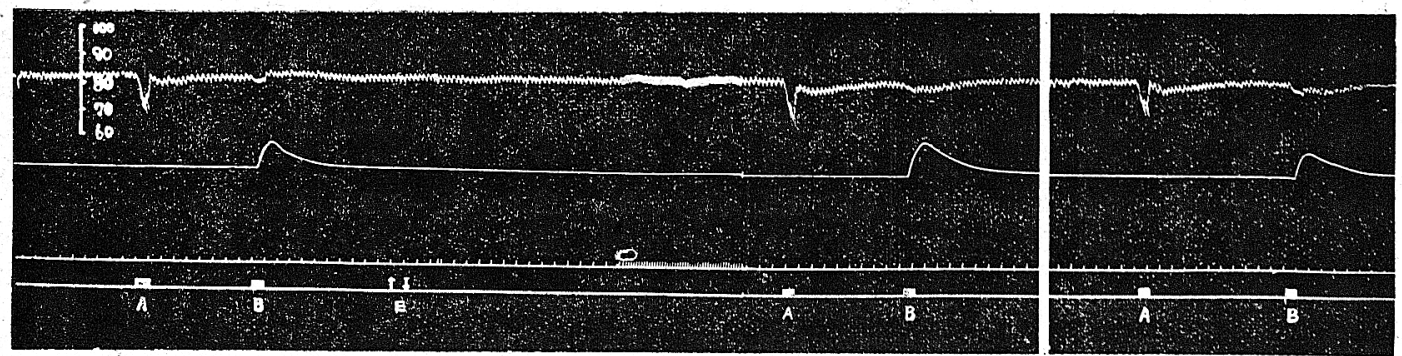

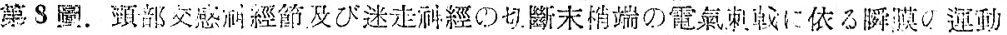

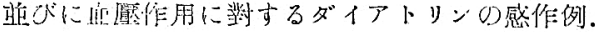

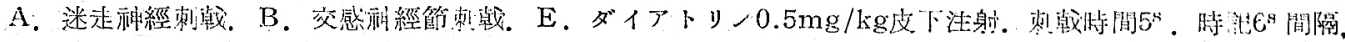

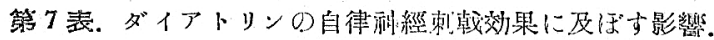

\begin{tabular}{|c|c|c|c|c|c|c|c|c|}
\hline \multirow{2}{*}{ 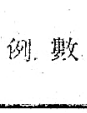 } & \multirow{2}{*}{ 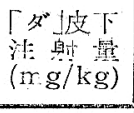 } & 交 & 感 & 神 & 經 & \multicolumn{3}{|c|}{ 副交 憼 刑 } \\
\hline & & $\begin{array}{l}81: \text { 息i } \\
\text { (Cis) }\end{array}$ & $\begin{array}{l}\text { 沬身i } \\
\text { Ccn }\end{array}$ & $0^{\mathrm{m}}$ 徯 & $\begin{array}{l}30^{\mathrm{m}} \text { 後 } \\
(\mathrm{cm})\end{array}$ & $\begin{array}{l}\text { 渄搝 } \\
(\mathrm{cm})\end{array}$ & $\begin{array}{c}\text { 洞鼻: } 10^{\mathrm{n}} \text { 後 } \\
(\mathrm{cm})\end{array}$ & $\begin{array}{l}30 \mathrm{~m} / \mathrm{u}^{2} \\
(\mathrm{~cm})\end{array}$ \\
\hline 1 & 0.1 & 19.5 & $(t)$ & 0.3 & (土) 0 & 20.0 & $( \pm) 0$ & (士) 0 \\
\hline 2 & 0.1 & 20.0 & $(t)$ & 0.2 & $( \pm) 0$ & 19.0 & $( \pm) 0$ & $( \pm) 0$ \\
\hline 3 & 0.5 & 20.0 & $(-)$ & 0.7 & $(+) 0.5$ & 20.0 & $(-) 0.2$ & $( \pm) 0$ \\
\hline 4 & 0.5 & 18.0 & $(-)$ & 0.5 & $(+) 0.3$ & 18.0 & $(-) 0.5$ & $(-) 0.3$ \\
\hline 5 & 1.0 & 19.0 & $(-)$ & 0.5 & $(+) 0.5$ & 16.0 & $(-) 0.5$ & $(-) 1.0$ \\
\hline 6 & 3.0 & 18.0 & $(-)$ & 0.5 & $(t) 0.5$ & 18.0 & $(-) 1.0$ & $(-) 2.0$ \\
\hline 7 & 5.0 & 19.0 & $(-)$ & 0.5 & $(+) 0.8$ & 18.0 & $(-) 2.0$ & $(-) 3.0$ \\
\hline
\end{tabular}

F。抗とスタミン製のアミノオキシダーゼに数する作用

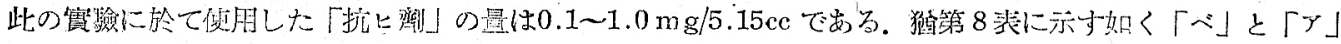
とはアミノオキシダーゼの作朋を

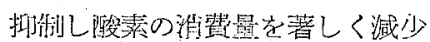
したが、「ダ」にはかかる著明な䧣 素抑㑬作用は認奴なかつた。

\section{IV. 總括並びに考察}

上述の成細からすれば「べ」

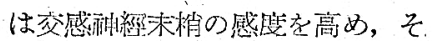

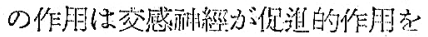

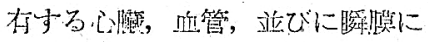

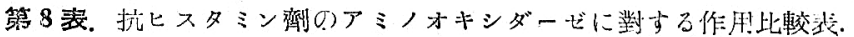

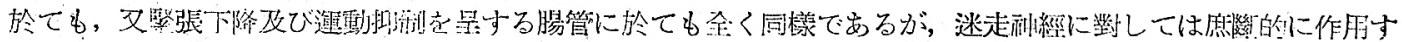

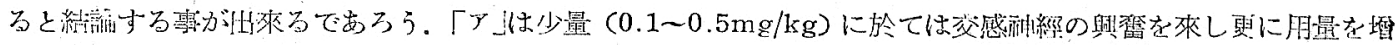

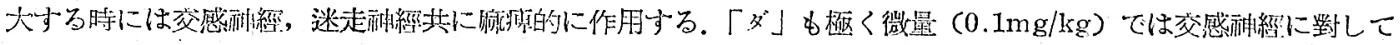

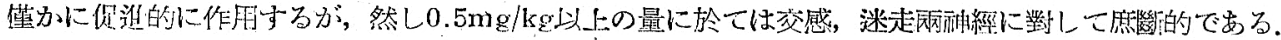




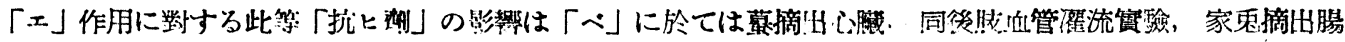

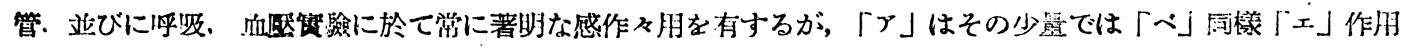

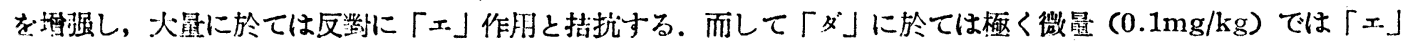

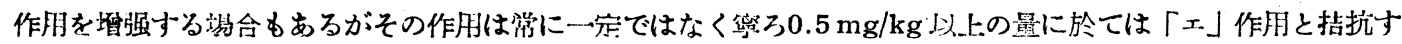

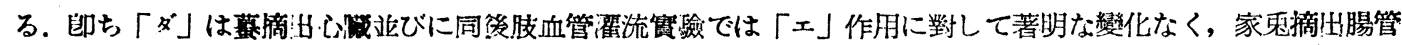

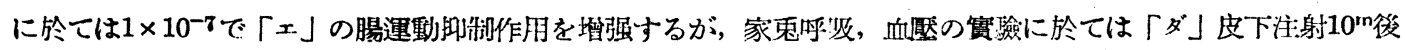

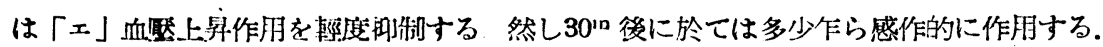

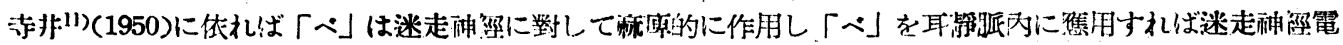

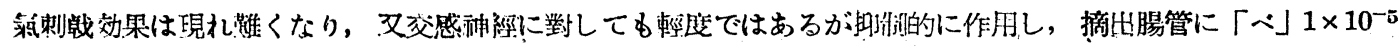

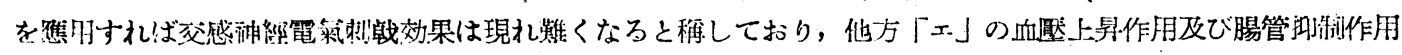

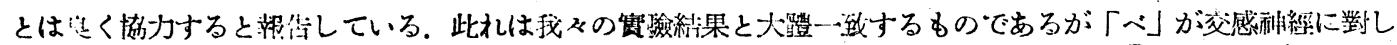

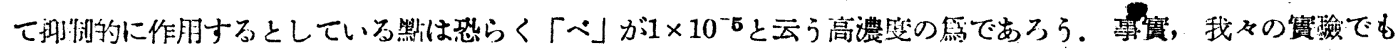

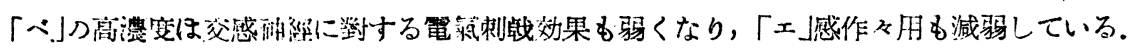

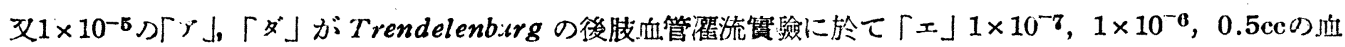

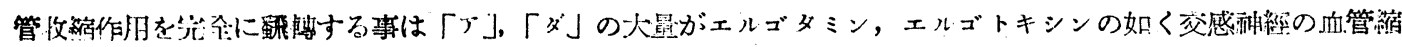

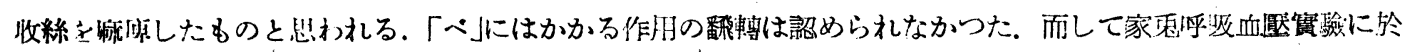

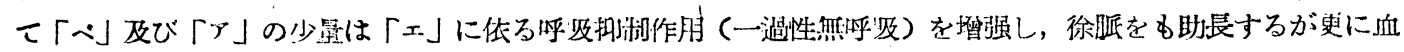

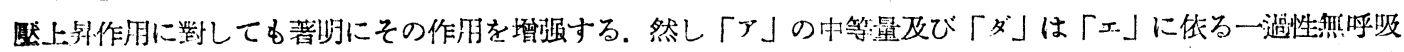

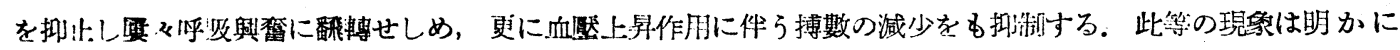

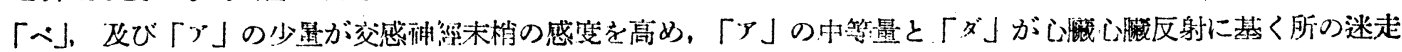

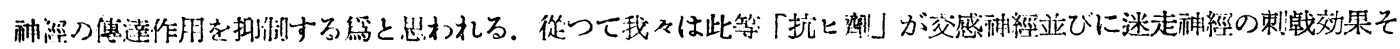

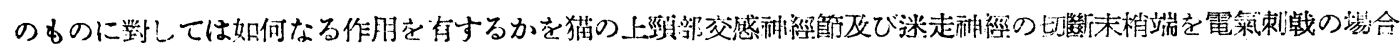

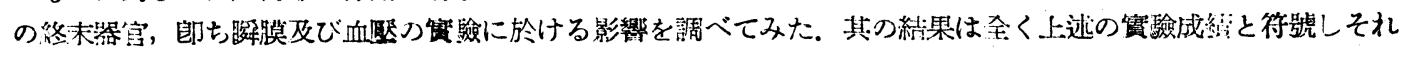
管艺滿足せしめるあのであつた。

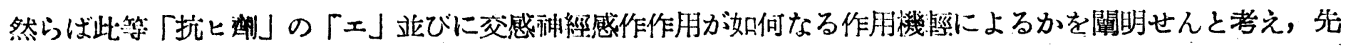

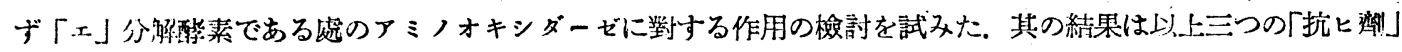

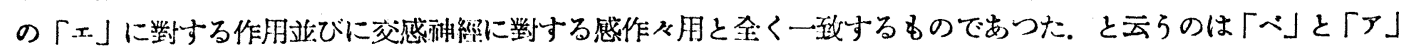

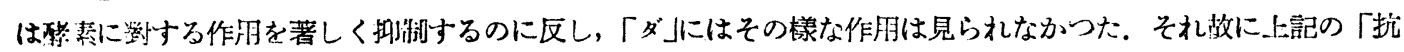
七判」の「土」感作及月は抗アミノオキシダーゼ作用に依るものと想傢されるのである。

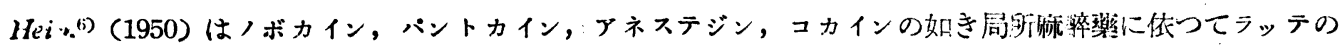

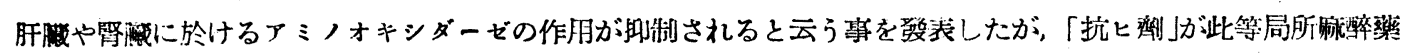

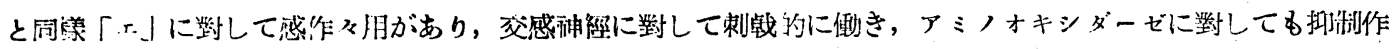

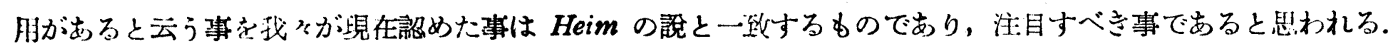

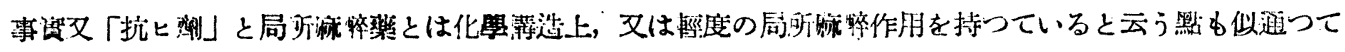
いる.

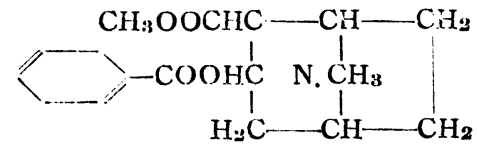

Cocaine<smiles>CCN(CC)CCOC(=O)c1ccc(N)cc1</smiles>

Procaine

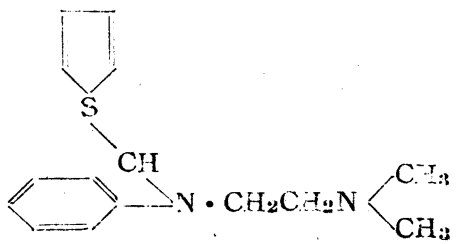

Diatrin 


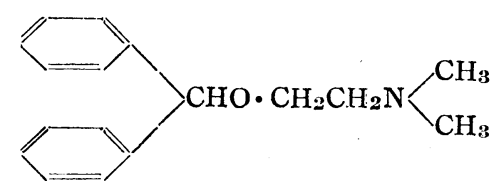

Benadryl

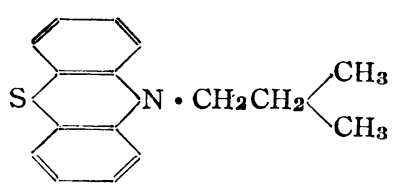

Anergen

第 9 圆. 局所麻醉藥と抗ヒスタタミン劑との化學構逜の類似點.

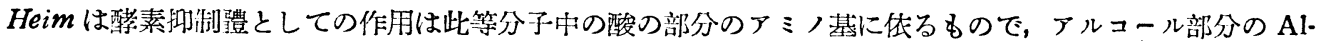

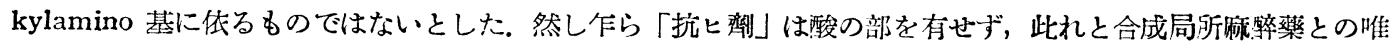
一の共通點はそれ等分子中に Dialkylaminoalkyl 基が存在すると云う事である.

此の樣にHeim の概念は我々の結果老說明し得ず，㿾ろアミノォキシダーゼ抑制作用は此の Dialkylaminoalkyl 基に由り弓ると思われる。

一方 Soehring7) (1949) はノボカインの治療作用はノボカインではなくて，この體內に於ける襝化を通じて 出來たDiäthylaminoäthanolに依るものとした. Hanschild ${ }^{8)}$ (1948) は Diäthylaminoäthanol が著しくTren-

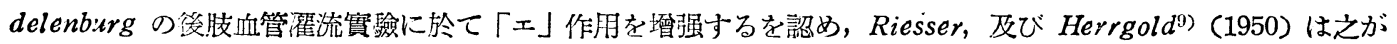

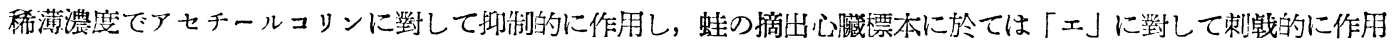
すると云う事を說明した. 然し乍ら Hanschild ${ }^{18)}$ (1943)は溫血動物に於てはこの「エ」感作々用は認められな いと剘告している，

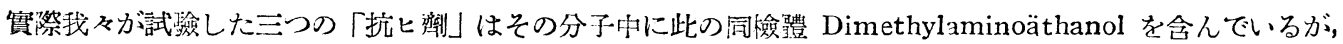
エーテル文はアミンとルて固く分子刚に結合されて居る䉆, 此等は Diäthylaminoäthanol のエステルである局

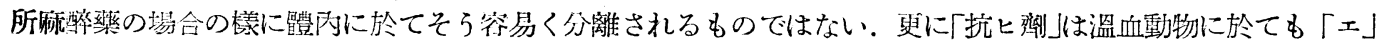
作用を增强した，此の樣に Dialkylaminoalkyl 基は「抗七劑」の「エ」感作々用に於て重要な役割を持つてい、 るものと考えられるが，此の基の存在も本作用の全部を說明し得ず，獍し「ダ」は分子中に本基を有するに拘ら ず「へ」の樣なはつきりとした感作々用は持たないし，アミノォキシダーゼ抑制作用も有せず，從つて同時に分

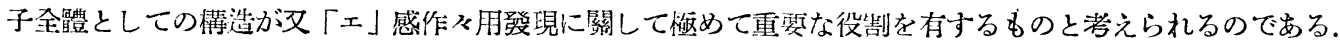

\section{V. 結 論}

1. Benzhydryldimethylaminoethanolether (Benadryl) と $\mathrm{N}, \mathrm{N}$-thiodiphenyl-N; $\mathrm{N}^{\prime}$ dimethylenediamine (Anergen) はエピレナミンと艾感神經刺啅に對して末梢器官感作々用があり，アミノォキシダーゼに對し ても抑制作用がある。

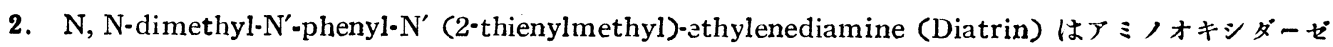

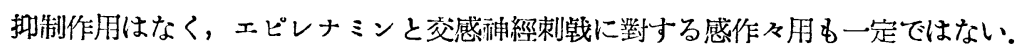

3. 以上三つの抗ヒスダミン劑の各種臟器の機能に對する作用を明かにした,

稿を終るに當り終始御懇篤な御指莩前に御校閱を賜わつた恩師染秋要教授に衰心より感謝け意を表すると共 に種々有益なる御助言を戴いた九州大學福田得志教授前に貴重な藥品を贈與下さつたWilliam R. Warner 會融 研究所長 Dr. O. Anido 氏に對し深甚なる謝意を表します.

\section{引用 書 目}

1) Jenning, H.:(2) より引用.

2) Mancke, R. u. Orzechowski, G.: Arch. exper. Path. u. Pharmakol. 205, 223 (1948).

3) 監谷信男: 朝鮮䣽會誌 95, 39 (1927).

4) Laewen, A. u. Trendelenbirg, P.: Arch. exper. Path. u. Pliarmakol. 51, 415 (1904).

5) Magnus, R.: Pfïgers Arch. 102, 123 (1904). 
6) Heim, F.: 同誌 209, 181 (1950).

7) Soehring: Pharmazie 4, 319 (1949).

8) Hauschild: 同誌 205, 203 (1949).

9) Riesser, O. u. Herrgold: 同誌 209, 95 (1950).

10) Hauschild: 'Arch. exper. Path. u. Pharmakol. 201, 559 (1943).

11）寺井正士: 醫學研究 20，59 (1950). 


\section{BREVIARIA}

scopic findings showed that these capillary-like patterns are of a degene rative sign of leucocytes, so that if only the cultivating conditions, which are mainly related to their physical properties in this case, were suitable enough, these patterns would be ever proliferating.

Author

41. OGIU, Kikuo, SHIMAMOTO, Kiro and MATSUBARA, Takayoshi. Department of Pharmacology, Faculty of Medicine, Kyoto University, Kyoto Chemical and pharmacological studies on the in vitro cultivated ergot (Report 2) (pp. 351-355) Tables 2

In succession to the first report on the pharmacological studies on the in vitro cultivated ergot, the fluid extract of the mycelium and the filtrate of some ergot species (Claviceps purpurea separated by Prof. Katagiri, Claviceps purpurea separated from the rye-ergot, which were imported from North America and Claviceps separated from ergot of Agrogyrum semicostatum), which were cultivated in vitro on various synthetic culture media modifing the cultural $\mathrm{pH}$, cultural period and cultural temperature, were studied systematically. The results obtained are as follows: 1 ) The oxytocic potency of the fluid extract of the mycelium of the third were 4 to 8 times stronger than that of the first and 2 to 4 times stronger than the second on the extirpated virgin guinea pig's uterus in vitro. Only the extract of mycelium of the latter showed the cock comb reaction and the adrenolytic action on the extirpated uterus and ileum of rabbit in vitro. As the amounts of histamine in these extracts, assayed by Dale-Schulz's method using the extirpated guinea pig's ileum, were considerably small, the oxytocic sub- stances in the extracts resulted from the specific ergot alkaloids. 2) On the other hand, the fluid extracts of all the fltrates showed the cock comb reaction and adrenolytic action as well as the oxytocic action similar to that of the mycelium. 3) The alternation of the cultural conditions using various composition of natural and artificial cultural media and $\mathrm{pH}$ did not modified the pharmacological action essentially. However the oxytocic potency of the fluid extract of mycelium on artificial cultural media were somewhat stronger than that on natural cultural media. 4) Alternation of the cultural period for 1 to 4 weeks and the cultural temperature for 5 to $27^{\circ} \mathrm{C}$ also did not modified the pharmacological action of the fluid extract of mycelium and filtrate.

Authors

42. MATSUBARA, Takayoshi. Department of Pharmacology, Faculty of Medicine, Kyoto University, Kyoto Pharmacological action of the fluid-extract of in vitro culture of Claviceps on Phragmites prostratus Makino (pp. 357-370) Tables 2

A pharmacological experiment was carried out on the fluid-extract of in vitro-culture of Claviceps parasited on "Tsuruyoshi," Phragmites prostratus Makino, grown wildly in the Kyoto district and gathered in December 1949, and it was proved that the fluid-extract exerted a strong contraction of the isolated uterus in rabbits and guineapigs, which may be attributed to ergo: tamine, probably being existed in this fluid-extract.

Author

43. UCHIDA, Tohoru. Department of Pharmacology, Nihon Medical School, 


\section{BREVIARIA}

Tokyo Antihistaminics as epinephrine sensitizer (pp. 371-383) Tables 8 Illus. 8

The present paper reports results of studies on influence of antihistaminics over the effects of epinephrine and stimulation of the sympathetic and vagus on functions of various organs as well as the activity of aminoxidase. 1) Benzhydryldimethylaminoethanolether (Benadryl) and $\mathrm{N}, \mathrm{N}$-thiodiphenyl-N; $\mathrm{N}^{\prime}$ dimethylethylenediamine (Anergen) sensitize peripheral organs against epinephrine as well as the sympathetic stimulation, and they inhibit the aminoxidase activity. 2) $\mathrm{N},-\mathrm{N}$-dimethyl$\mathrm{N}^{\prime}$-phenyl-N' (2-thienylmethyl)-ethylenediamine (Diatrin) does not inhibit the aminoxidase, and its epinephrine and sympathetic sənsitization is unpronounced and variable. 3) Effects of the three antihistaminics on functions of various organs were determined.

Author

44. OKAMOTO, Goichi. Department of Pharmacology, Faculty of Medicine, Kyote University, Kyoto Studies on the synthetic anticonvulsants (6) Pharmacology of $\alpha$ - and $\beta$-TNP (pp. 384-392) Tables 7 Graphs 2 Illus. 1

The potent anticonvulsant action with longer duration has been proved with 3(1,2,3,4-tetrahydro-8-naphthyloxy)-1,2-propanediol $(\alpha$-TNP) and 3-1,2,3,4-tetrahydro7-naphthyloxy)-1,2-propanediol ( $\beta$-TNP) by Omiya (see this Folia, vol. 49, no. 4, pp. 159, 1953). The author has proved also that they have the analgesic, antihistaminic, anti-cholinergic and quinidine-like actions.

$$
\text { Yamada-Kyoto }
$$

45. SHIMAMOTO, Kiro, FUJITA, Sadao, YASUHARA, Motohiro and OGAWA, Yasunao. Dapartment of Pharmacology, Faculty of Madicine,
Kyoto University, Kyoto The constrictor action of adrenaline and acetylcholine on the extirpated vessels (pp. 393-401) Tables 8 Illus. 4

Using the drop-timer, designed lately by the authors, the blood vessels of the extirpated frog's leg and of the rabbit's ear were perfused by the usual laboratory technic with Ringer-Locke's solution. The mode of action of adrenaline and acetylcholine were studied by discussing the effects of some other autonomic drugs upon the action of adrenaline and acetylcholine. Results : 1) At the beginning of the perfusion of the frog's leg-vessels, the rhythmic increase and decrease of outflow of perfusate were observed. 2) At the beginning of the perfusion of both preparations, it was often seen that the injection of adrenaline $\left(10^{-7}-10^{-9}\right)$ increased the outflow, but after the preparations were stored in $0^{\circ} \mathrm{C}$ for $12 \mathrm{hrs}$, the increase of outflow could be seen no more, but only a decrease of outflow. 3) Acetylcholine decreased the outflow of the frog's legvessels almost without exception, but increased the outflow of the rabbit's ear-vessels occasionally, which responded to a decrease of outflow of the rabbit's ear-vessels occasionally, and responded to a decrease of outflow without exception after it had been stored in $0^{\circ} \mathrm{C}$ for $12 \mathrm{hrs}$. 4) Parasympathicomimetics, such as betaine methyl- and ethylesters and pilocarpine inhibited the decreasing action of adrenaline in dilute concentration, but potentiated in high concentration. Pilocarpine also inhibited the decreasing action of acetylcholine. 5) The decreasing actions of adr enaline and acetylcholine were potentiated by eserine and DFP in dilute concentration, but they were inhibited or prevented by large doses of DFP. 6) The decreasing action of adrenaline and acetylcholine were potentiated by the amall 